\title{
The Münster Rising, Memories of Violence, and Perceptions of Dissent in Restoration England
}

\author{
Andrew Crome \\ Department of History, Politics \& Philosophy, Manchester Metropolitan University, \\ Manchester, UK \\ Email: a.crome@mmu.ac.uk
}

\begin{abstract}
This article examines the ways in which the violent Anabaptist rising at Münster in 1533-5 was reinterpreted in Restoration England. Historians have often recognized that the incident was used to attack English Baptists in the seventeenth century, but there has been little systematic exploration of the processes behind this. This article suggests that recollections of Münster in later seventeenth-century England were a species of 'cosmopolitan memory' an internationally shared memory of trauma put to distinctive local uses. References to Münster served as ways for English writers to tie nonconformists to specific acts of religious violence in England, including the Civil Wars and Thomas Venner's 1661 rising in London, without directly recalling these events. Historical discussions of the Münster rising therefore often directly transformed German Anabaptists into Quakers or Fifth Monarchists. Condemnations of the violence in the German city were also used by Congregationalists and Presbyterians to differentiate themselves from Baptists and Quakers and to emphasize their orthodoxy. Some Baptist writers responded by disclaiming their links to continental Anabaptists, while others moved to question the established historiography around the Münster rising. This article demonstrates these points through a range of sources, including sermons, letters, commentaries, controversial literature, and almanacs.
\end{abstract}

Complaining about the treatment of Baptists by the Restoration press in 1660 , the author of Moderation: or arguments and motives tending thereunto turned to the abuses of history by their enemies. Condemning the 'grand impeachment' of those called 'Anabaptists', he bemoaned the fact that his fellow believers were accused of opposing the magistrate 'upon which account the Munster Tragedy is so much and so often in all places (by Prints, and otherwise) laid to their charge, as indeed it could not lightly be more, if those bearing that name in England had been the very individual actors thereof at Munster'.

\footnotetext{
${ }^{1}$ S. T., Moderation: or arguments and motives tending thereunto (London, 1660), pp. 13-14.
} 
This was not an exaggerated claim. The site of an infamous Anabaptist rising in 1534 led by Jan van Leiden, the German city of Münster was a place with powerful implications for the Protestant psyche. Over the course of the Restoration period and into the eighteenth century, the Münster affair was repeatedly invoked as shorthand for political chaos and the dangers of religious dissent. As General Baptist minister and controversialist William Russel complained in 1697, 'John of Leyden is the man that at every turn our Enemies take occasion to upbraid us with.'

This article explores the way in which Baptists and other dissenters were attacked through accusations of links to the 1534 Anabaptist commonwealth in Münster. While seventeenth-century dissenters denied any historical legitimacy to these links, they nonetheless remained in circulation. The historical memory of Münster knotted itself to accounts of the Civil War and Interregnum in conformist works, particularly in the aftermath of Thomas Venner's Fifth Monarchist rising in January 1661. This article shows ways in which this memorialization of Münster was fashioned, resisted, and actively used by different groups in print. The result was that Münster served as a cultural symbol that helped to define the limits of acceptable religious practice.

Following the 1660 Act of Indemnity and Oblivion, in which the animosities of the Civil Wars, regicide, and Interregnum were ordered to be forgotten, invocations of Münster were used by conformists as a way to recall Civil War tensions without directly naming them. ${ }^{3}$ Yet they also offered something more than this - a connection to reformed tradition, implications about governance in church and state, and a way of legitimating the regime's Protestant credentials. The Münster rising's application to English events is therefore an example of what Daniel Levy and Natan Sznaider labelled 'cosmopolitan memory', in which memories of international events connect individuals into a broad memory-structure while adapting to local traditions. ${ }^{4}$ This process transposed events in sixteenth-century Germany onto seventeenth-century English soil, transforming English Baptists into violent rebels.

The events at Münster in the 1530s were notorious in early modern Europe. In 1533, the city underwent a shift from Catholicism to Lutheran Protestantism under minister Bernhard Rothman. Falling increasingly under the influence of Anabaptist preachers such as Jan Matthys, Münster soon became a haven for the group, as the city elected an Anabaptist council and subsequently faced armed opposition from the prince-bishop Franz von Waldeck, who besieged it from February 1534 to June 1535. As the siege took its toll, rhetoric from within Münster became more violent. In December 1534, Rothmann published Van der Wrake ('Consoling Message of Vengeance') calling for the godly to

\footnotetext{
${ }^{2}$ William Russel, A vindication of the baptized churches (London, 1697), p. 67.

${ }^{3}$ Warren Johnston, Revelation restored: the apocalypse in seventeenth-century England (Woodbridge, 2011), pp. 81-3.

${ }^{4}$ Initially in Daniel Levy and Natan Sznaider, 'Memory unbound: the Holocaust and the formation of cosmopolitan memory', European Journal of Social Theory, 5 (2002), pp. 87-106. See also The Holocaust and memory in the global age (Philadelphia, PA, 2005); and Human rights and memory (University Park, PA, 2010).
} 
execute judgement on sinners on earth in order to usher in the millennial period. On Matthys's death, his position was taken by the tailor-prophet Jan Bockelson, better known as Jan van Leiden/John of Leiden, who proclaimed himself apocalyptic king and instituted a community of shared goods and polygamy. As the city suffered the effects of starvation, and its new king became increasingly paranoid, Münster was betrayed to the besiegers in June. The prince-bishop's forces slaughtered most male Anabaptists. In January 1536, van Leiden, Münster citizen and key ally Bernd Knipperdollink, and another leader, Bernd Kretchtink, were brutally executed. The authorities placed their bodies in cages hung on the tower of St Lambert's Church, where the (now thankfully empty) cages remain in place today. ${ }^{5}$

As Michael Driedger notes, propaganda surrounding atrocities and excesses in Münster began to circulate while the city was under siege. Later historians, both in the early modern and modern period, have often used these descriptions uncritically. This has served to pathologize early modern Anabaptists, imposing an inappropriate link between apocalypticism and violence. ${ }^{6}$ It remains important that we foster a healthy scepticism when reading sixteenth-century accounts of the siege written by the Anabaptists' enemies. However, this article does not aim to explore events at Münster themselves, or the reliability of the major accounts produced of them. Instead, it focuses on the ways in which the incident was remediated and remembered in England over a century later, and why that memory had such polemical resonance.

How did an isolated incident in 1530s Germany continue to have cultural relevance in England for the next two hundred years, and why did it merge with memories of the Civil Wars? Two particular approaches drawn from the study of both historical and contemporary religious groups can shed light upon this process. Building on studies of 'collective memory', ${ }^{8}$ Daniel Levy and Natan

\footnotetext{
${ }^{5}$ There are a number of detailed examinations of events at Münster. See Willem de Bakker, James Stayer, and Michael Driedger, Bernhard Rothmann and the Reformation in Münster, 1530-35 (Kitchener, 2009); Sigrun Haude, In the shadow of 'savage wolves': Anabaptist Münster and the German Reformation during the 1530s (Boston, MA, 2000); Ralf Klötzer, 'The Melchorites and Münster', in James D. Roth and James Stayer, eds., A companion to Anabaptism and Spiritualism, 1521-1700 (Leiden, 2007), pp. 217-56.

${ }^{6}$ Michael Driedger, 'Thinking inside the cages: Norman Cohn, Anabaptist Münster, and polemically inspired assumptions about apocalyptic violence', Nova Religio, 21 (2018), pp. 38-62.

${ }^{7}$ Christopher S. Mackay has recently published English translations of the major accounts of the siege. The first, written by former Münster resident Hermann von Kerssenbrock in the 1560s or 1570s (but not published until 1771), and the second by Henry Gresbeck, who claimed to have betrayed the city. See False prophets and preachers: Henry Gresbeck's account of the Anabaptist kingdom of Münster, trans. Christopher S. Mackay (Kirksville, MO, 2016); and Hermann von Kerssenbrock, Narrative of the Anabaptist madness: the overthrow of Münster, the famous metropolis of Westphalia, trans. Christopher S. Mackay (Leiden, 2007).

${ }^{8}$ Collective memory formation refers broadly to processes of remembering, commemorating, and generating memory on a socio-cultural level. The term developed from Maurice Halbwachs's work in the 1920s, translated into English as On collective memory, trans. and ed. by
} 
Sznaider developed the concept of 'cosmopolitan memory' in their work on the cultural memory of the Holocaust. Writing against critiques that claimed that globalized memory was inauthentic due to its transnational basis, they argued that images and historical memories of the Holocaust produced a shared memory culture that established the Shoah as a universalized symbol of evil. Yet, the precise meaning of the Holocaust varied in different areas of the world: 'its meanings evolve from the encounter of global interpretations and local sensibilities'.9 Although this concept developed in relation to the globalized media-saturation of the modern world, it has a number of resonances with the situation in early modern Europe. Of course, no contemporary theory can be applied to the past in its entirety. Levy and Sznaider emphasize the crucial role of electronic media in the formation of cosmopolitan memory and would therefore deny a pre-modern application. The precise nature of memory formation is in part a result of the media structure of a particular period, and it would be anachronistic to claim that the forms of cosmopolitan memory in the early modern period were precisely the same as those in the internet age. Nonetheless, it is possible to suggest that printed media were used to help construct a consensus memory that adapted remembrance of a European tragedy into a distinctly English event. This is not to claim that the use of Münster to portray Anabaptists as dangerous fanatics was specific to England (which it unquestionably was not), but that English writers adapted and shaped it in ways unique to their context and experiences of religious violence. In this sense, 'cosmopolitan memory' may be less a new phenomenon stimulated by globalization, but instead the recurrence (or persistence) of pre-modern forms of transnational memory practices. Indeed, for Levy and Sznaider it was the fracture and eclipse of modernity, rather than modernity itself, that allowed 'cosmopolitan memory' to emerge. ${ }^{10}$

Recently, Judith Pollmann has applied the concept to early modern Europe, particularly to international memories of religious violence in the period. She demonstrates the way in which in the 'black legend' of Spanish atrocities in America, the bitter violence in the Netherlands, and massacres in the French Wars of Religion became lenses through which Protestants understood Catholic violence. ${ }^{11}$ In this article, I argue that Münster represents one of the

Lewis Coser (Chicago, IL, 1992). Numerous other terms, such as 'cultural memory' (e.g. Jan Assmann, Cultural memory and early civilization (Cambridge, 2011)) and 'social memory' (e.g. James Fentress and Chris Wickham, eds., Social memory (Oxford, 1992)) have been developed in order to provide more specificity to the concept. For a good overview of the background of these terms, see Jeffrey K. Olick and Joyce Robbins, "Social memory studies: from "collective memory" to the historical sociology of mnemonic practices', Annual Review of Sociology, 24 (1998), pp. 105-40, and for more recent debates, see the opening six chapters in Anna Lisa Tota and Trever Hagen, eds., Routledge international handbook of memory studies (London, 2016), pp. 7-75.

${ }^{9}$ Levy and Sznaider, 'Memory unbound', p. 92.

${ }^{10}$ Ibid., p. 89.

${ }^{11}$ Judith Pollmann, Memory in early modern Europe, 1500-1800 (Oxford, 2017), pp. 159-84. On the black legend, see also the essays in Margaret R. Greer, Walter D. Mignolo, and Maureen Quilligan, eds., Rereading the black legend: the discourses of religious and racial difference in the Renaissance empires (Chicago, IL, 2008). For its influence on Protestant conceptions of later 
clearest instances of this process. Münster became archetypal of all Anabaptist behaviour in Reformation Europe, but was applied in unique ways in England. These existing ideas helped contemporaries to make sense of recent violence within a broader framework. The transnational community of reformed Protestants developed a sense of wider identity through their shared condemnation of the Roman church, their martyrologies, and a series of landmark historical events (e.g. the St Bartholomew's Day massacre, the Synod of Dort). Condemnation of Münster, similarly, allowed a shared historical interpretation that served both to demonstrate the importance of political order and to draw boundaries around valid membership of the reformed community (firmly excluding Anabaptists). While this worked on an international level to foster a broad Protestant memory culture, at the same time it took on distinctive local colourings and implications. For example, memories of Münster in Amsterdam were linked to the Anabaptist rising in the city in 1534, commemorated by instituting an annual civic procession. ${ }^{12}$ The chaos of the Anabaptist rising was transposed to England and became synonymous with memories of the disorder of the 1640s and 1650s.

Other recent theoretical work can help suggest why this was the case in the context of early modern England. Lynn Neal's study on cultural memory and the way that contemporary culture understands episodes of religious violence offers the second theoretical lens I will apply here. Neal argues that popular narratives of episodes of religious violence (such as the 1978 Jonestown murder/suicides or 1997 Heaven's Gate suicides) serve as ways for setting clearly defined boundaries between religion and madness, establishing acceptable limitations for engaging with minority religious groups in broader society. These narratives rescript the past by establishing incidents such as Jonestown as paradigmatic examples of the threat posed by minority religions to social order. They therefore conflate separate episodes of religious violence in the popular mind, with differences between groups effaced in favour of narratives that restate the status quo. ${ }^{13}$

In an atmosphere of official political oblivion in England in the 1660s, the Münster atrocities fulfilled this role for the authorities. ${ }^{14}$ They represent one example of what Matthew Neufeld has described as the practice of "public remembering' in the period. The term refers to the process of 'constructing

Catholic violence, see particularly Patricia Gravatt's essay in the collection, 'Rereading Theodore de Bry's black legend', pp. 225-43.

${ }^{12}$ Judith Pollmann and Erika Kuipers, 'Introduction: on the early modernity of memory', in Erika Kuijpers, Judith Pollman, Johannes Müller, and Jasper van der Steen, eds., Memory before modernity: practices of memory in early modern Europe (Leiden, 2013), p. 6; Gary K. Waite, 'Celebrating the victory over the Anabaptists: the ceremonial aftermath of Jan van Geelen's attempt on Amsterdam', Mennonite Quarterly Review, 63 (1990), pp. 298-300.

${ }^{13}$ Lynn Neal, 'Rescripting the past: suicide cults on television', in James R. Lewis and Carol M. Cusack, eds., Sacred suicide (Farnham, 2014), pp. 253-69.

${ }^{14}$ As Ann Hughes has shown, as early as 1645 there is evidence of deliberate 'forgetting' of particular aspects of the conflict for both communal and psychological reasons. See "'The accounts of the kingdom": memory, community and the English Civil War', Past \& Present, 230, Supplement 11 (2016), pp. 311-29. 
and disseminating representations of public events, usually in the form of a story', primarily through print in order to achieve wider circulation. ${ }^{15}$ Developing Neufeld's work, which focused on representations of the Civil Wars themselves, this article examines the way in which an additional story could be transposed onto these direct historical accounts. Münster provided a snapshot of royalist critiques of their enemies in the 1640s and 1650s. Including rebellion against the established authorities, millenarian excitement, radical sectaries, and violent attacks on religious orthodoxy, it linked to ongoing concerns about 'radical' groups such as Quakers and Fifth Monarchists. Finally, being linked specifically to Anabaptist violence already condemned by the magisterial reformers, it allowed Congregationalists and Presbyterians to differentiate themselves clearly from the 'radicals', and to profess loyalty to both the English authorities and to established reformed tradition. In other words, it served as a healing ritual through which to process the chaos of the 1640s and 1650s.

\section{II}

Following the fall of the city, Catholic apologists quickly emphasized events in Münster as proof of the dangerous consequences of Protestant thought and lay interpretation of the scriptures. This unquestionably influenced the magisterial reformers' steadfast rejection of millennialism in the later sixteenth century, with Münster seen as a dramatic demonstration of the danger of the belief. ${ }^{16}$ In the face of the subsequent pacifism of Anabaptists, the Münster affair also helped to justify their continuing persecution by the magistrate. English government officials and intellectuals were familiar with events in Münster during the siege, and were concerned both to avoid Anabaptist settlement in England and to placate potential Lutheran allies with firm official condemnations of the group. As early as 1535, an English pamphlet providing an overview of Anabaptist excesses and the city's fall was available. ${ }^{17}$ Neither was the affair quickly forgotten, appearing in later English anti-Anabaptist polemics such as William Turner's 1551 A preseruative, or triacle, agaynst the poyson of Pelagius, ${ }^{18}$ as well as being one of several continuing justifications for the sporadic persecution of foreign Anabaptists in Edward's and

\footnotetext{
${ }^{15}$ Matthew Neufeld, The Civil Wars after 1660: public remembering in late Stuart England (Woodbridge, 2013), pp. 8-9 (quotation at p. 8). Although primarily focused on print, Neufeld notes other forms through which these memories could circulate, including sermons, letters, and petitions.

${ }^{16}$ Crawford Gribben, Evangelical millennialism in the trans-Atlantic world (Basingstoke, 2010), pp. 20-8. A number of confessional statements condemn millennialism, including the English ' 42 Articles' (1553) and the Second Helvetic Confession (1566).

${ }^{17}$ A treune nyeuu tydynges of the wo[n]derful workes of the rebaptisers of Mu[n]ster in Westuaell (Antwerp, 1535). The work, the only copy of which survives in the Folger Shakespeare Library, was highlighted and transcribed in Albert Pleysier, Henry VIII and the Anabaptists (Lanham, MD, 2014), pp. 134-42. A digitized version is now available on the Folger's website.

${ }^{18}$ For example, when Turner defends 'my poore and innocente infants' against 'the doctryne of your sedytions [sic] and mourderynge Anabaptistes: which destroyed the noble citie of Munster, in Westphali'. William Turner, A preseruative, or triacle, agaynst the poyson of Pelagius (London, 1551), sig. fiv-fiir.
} 
Elizabeth's reigns. ${ }^{19}$ Events at the city continued to cause embarrassment to European Anabaptists throughout the seventeenth century. As Jaap Geraerts notes, martyrologies such as Hors de Ries's Historie der martelaren (1615) deliberately skipped over the years 1533-5, while Thieleman van Braght's Het bloedig tooneel (1660) condemned the Münsterite violence while also playing down connections between his subjects and the city. ${ }^{20}$

Given this, it is unsurprising that events in the German city continued to appear in debates about the position of Baptists in England during the 1640s and 1650s, despite the limited connections between English Baptists and those on the continent. ${ }^{21}$ What was new was the way in which they were linked to contemporary disturbances as Baptists became more visible. While I agree with Driedger that use of Münster represents a 'meme' through which Anabaptist groups have been ahistorically othered, it was also the case that the Münster narrative was adapted from a broader reformed memory culture, while doing specific historical work in seventeenth-century England. ${ }^{22}$

The tumult of the early 1640s in England saw the publication of titles such as A short history of the Anabaptists of High and Low Germany and A warning for England, especially for London in the famous history of the frantick Anabaptists in $1642 .{ }^{23}$ Münster served as a symbol of the chaos that might be unleashed in a civil war. ${ }^{24}$ One of the most well-known of the anti-Baptist texts, Daniel Featley's 1645 The dippers dip't (reprinted five times up to 1660), emphasized how Anabaptists 'infected and infested' it. ${ }^{25}$ Münster was never far from Featley's mind. In the account of his Southwark disputation with those he labelled 'Anabaptists' in October 1642, he responded to the claim that the 'Saints' (gathered congregation) had the right to call a pastor with the marginal remark: 'Such saints as John of Lydan, who had 15. wives; and Cniperdoling, who died like a beast. ${ }^{26}$ At the end of the book, Featley provided a 'Remarkable History of the

\footnotetext{
${ }^{19}$ On this, see Carrie Euler, 'Anabaptism and anti-Anabaptism in the early English Reformation: defining Protestant heresy and orthodoxy during the reign of Edward VI', in David Loewenstein and John Marshall, eds., Heresy, literature and politics in early modern English culture (Cambridge, 2006), pp. 40-58; Alastair Duke, 'Martyrs with a difference: Dutch Anabaptist victims of Elizabethan persecution', Nederlands Archief voor Kerkgeschiedenis/ Dutch Review of Church History, 80 (2000), pp. 263-81.

${ }^{20}$ Jaap Geraerts, 'The prosecution of Anabaptists in Holland, 1530-1566', Mennonite Quarterly Review, 86 (2012), p. 7. Thieleman van Braght's work is better known as the Martyrs mirror, an alternative title added to the 1685 revision. On this, see Keith L. Sprunger, 'Dutch Anabaptists and the telling of martyr stories', Mennonite Quarterly Review, 80 (2006), pp. 149-81.

${ }^{21}$ Matthew Bingham, Orthodox radicals: Baptist identity in the English Revolution (Oxford, 2019), pp. 90-117; Andrew Bradstock, Radical religion in Cromwell's England (London, 2011), pp. 2-7.

${ }^{22}$ Michael Driedger, 'Münster, monster, modernity: tracing and challenging the meme of Anabaptist madness', in Mark Jantzen, Mary S. Sprunger, and John D. Theisen, eds., European Mennonites and the challenge of modernity over five centuries: contributors, detractors, and adapters (North Newton, KS, 2016), Kindle edition, loc. 774-1162.

${ }^{23}$ J. F. McGregor, 'The Baptists: fount of all heresy', in Barry Reay and J. F. McGregor, eds., Radical religion in the English Revolution (Oxford, 1984), p. 26.

${ }^{24}$ Henry Parker, The manifold miseries of civill warre and discord in a kingdome (London, 1642), p. 4.

${ }^{25}$ Daniel Featley, Katabaptisi kataptystoi: the dippers dipt (London, 1645), p. 28.

${ }^{26}$ Ibid., p. 17. Those Featley debated disavowed the name 'Anabaptists' - they advocated an independent model of church governance and adult baptism.
} 
Anabaptists', offering readers a background to the group. 'Remarkable' as it may have been, it was unquestionably partisan. Münster, unsurprisingly, was prominent. After showing how Anabaptist doctrine had allowed for polygamy, murder, theft, and a willingness to overthrow the magistrate, he laid out a warning for readers who doubted that such things could happen in England:

It will be said that our Anabaptists in England were never arraigned, or condemned for any such crimes, and that they seem to be a sillie and harmlesse people: yet let us take heed how we suffer the egges of the cockatrice to remain amongst us; for when they be hatched there will break out of them most venomous serpents. ${ }^{27}$

The most notorious catalogue of the sectaries' sins also made repeated links to Münster. Thomas Edwards's Gangraena (1646) made several comparisons between the German Anabaptists and contemporary groups his fellow Presbyterians feared were destroying English religion. ${ }^{28}$ 'This Land is become already in many places a Chaos, a Babel, another Amsterdam, yea, worse we are beyond that, and in the high way to Munster (if God prevent it not)', ${ }^{29}$ he warned. An unidentified minister, writing to Edwards on 29 July 1645, echoed him in his condemnation of those keeping a Saturday Sabbath in his town: 'we are gone beyond Amsterdam, and are in our high way to Munster'..$^{30}$ Later, Edwards worried that 'many of the Sectaries will, as at Munster, run up and down naked in the streets, and come to those unheard of cruelties and prophanesses [sic] related by Historians of those Anabaptists. ${ }^{31}$ He closed the treatise by warning that he would rather fall with the Scottish Presbyterians than 'flourish for a while with the Sectaries...yea, then to be a king among them, as John of Leyden was at Munster, ${ }^{32}$ General and Particular Baptist declarations of loyalty to the magistrate issued in $1644,1647,1648,1659$, and 1660 all attempted to disavow connections to Münster. Yet, as J. F. McGregor noted, 'John of Leiden's ghost still haunted the saints. ${ }^{33}$

Viewed through the lens of cosmopolitan memory, fears such as Featley's represent a pre-mediation of memory, which laid the template for later interpretations of nonconformists as early as the 1640s. 'Historical' references to

\footnotetext{
${ }^{27}$ Ibid., p. 212.

${ }^{28}$ On Edwards and Gangraena, see Ann Hughes, Gangraena and the struggle for the English Revolution (Oxford, 2004).

${ }^{29}$ Thomas Edwards, The first and second part of Gangraena (3rd edn, London, 1646), 'The third part', p. 54.

${ }^{30}$ Ibid., 'A copy of some letters', p. 12. The pagination of this edition is irregular, and restarts with this section after p. 66. Although the Anabaptists did not keep a Saturday Sabbath in Münster, the practice was linked to nonconformity through the example of those such as John Traske in the 1610s, and a small number of English Baptists in later decades. See David S. Katz, Philo-semitism and the readmission of the Jews to England 1603-1655 (Oxford, 1982), pp. 18-41; and Bryan W. Ball, The seventh-day men: Sabbatarians and Sabbatarianism in England and Wales, 1600-1800 (Oxford, 1994).

${ }^{31}$ Edwards, The first and second part of Gangraena, 'The third part', p. 101.

${ }^{32}$ Thomas Edwards, The second part of Gangraena (London, 1646), p. 178.

${ }^{33}$ McGregor, 'Baptists', p. 55.
} 
Germany were localized and applied in distinctively English contexts. ${ }^{34}$ Although this initially focused on those labelled 'Anabaptists', references to Münster sometimes broadened outwards to include Independents and all those who did not support a national reformed church. The horrors of Münster were a useful argument against the dangers of separation from the national church and the resulting call for wider toleration. Stephen Marshall recounted the 'phrensies at Munster' as a 'monster' that was 'not yet forgotten'. Pointing at those who separated from the national church and declared it 'unclean', he noted that 'In such manner, began they of Munster. ${ }^{35}$ In 1648, Clement Walker's History of Independency warned that due to the actions of the army's Independent grandees 'All England is become as Munster was, and our Grandees suitable to John of Leyden, and Knipperdolling. ${ }^{36}$ Daniel Cawdrey's attack on John Owen in 1657 decried the encouragement of separation and tolerance of schism. Owen's claim that separation from the national church was justified if the state was inadequately reformed was dangerous: 'I will not exemplifie it nearer home; but I think I may safely say, this is an Anabaptistical Munster principle at the bottome: and say no more. ${ }^{37}$ In 1653, John Canne grumbled that 'there is such a noise of Munster' that Satan had undoubtedly inspired John of Leiden's actions so as to discourage future Christians from both questioning paedobaptism and exploring prophecy by linking them to the chaos. ${ }^{38}$

In the political confusion of late 1659 and early 1660, the spectre of Münster therefore raised its head when considering Independents' involvement in policy. After the excluded members returned to parliament in February 1660, one pamphlet warned them that they faced a choice between recapturing the blessings of Elizabeth's reign or a military dictatorship: 'Knipperdoling and John of Leyden are at your elbowes, make your election at your perill. ${ }^{39}$ Reminiscing on the same period in the mid-1660s, Presbyterian minister Henry Newcome remembered his fears that London would become a new Germany. Although the Restoration had led to his expulsion from the Church of England, and fanatics had never troubled him personally in 1660, 'all this I have suffered since, I look upon it as less than my trouble was from my fears then...A Munsterian anarchy we escaped far sadder than particular persecution. ${ }^{40}$

Quakers became the target of particularly vitriolic attacks that linked them with the German city. Already in the 1650s, critics condemned Quakers through allusions to Münster, an unsurprising comparison given both their successes in recruiting Baptists and their bellicose rhetoric of apocalyptic warfare ${ }^{41}$ For example, a translation of the sixteenth-century Walloon theologian

\footnotetext{
${ }^{34}$ Pollmann, Memory in early modern Europe, pp. 172-4.

${ }^{35}$ Stephen Marshall, An expedient to preserve peace and amity among dissenting brethren (London, 1647), pp. 32-3.

${ }^{36}$ Clement Walker, The history of Independency (London, 1648), p. 30.

${ }^{37}$ Daniel Cawdrey, Independencie a great schism proved against Dr. Owen (London, 1657), p. 190.

${ }^{38}$ John Canne, A voice from the temple (London, 1653), pp. 5-7 (quote at p. 5).

${ }^{39}$ Expedients for the publique peace (London, 1660), p. 14.

${ }^{40}$ Henry Newcome, The autobiography of Henry Newcome, M.A. (Manchester, 1852), pp. 118-19.

${ }^{41}$ T. L. Underwood, Primitivism, radicalism, and the lamb's war: the Baptist-Quaker conflict in seventeenth-century England (Oxford, 1997), pp. 1-19.
} 
Guy de Bres's history of Münster was published in 1659 by New England minister Joshua Scotton as The English Quaker, the German enthusiast revived. ${ }^{42}$ Richard Blome's 1660 Fanatick history, dedicated to Charles II, included helpful annotations that conflated the two groups - as when recording that missionaries were sent from Münster to the Netherlands, Blome remarked 'our Quakers have men everywhere'. ${ }^{43}$ Memories of Münster's sufferings therefore segued seamlessly into contemporary England. In Thomas Underhill's Hell broke loose, the Anabaptists morphed into Quakers: the same missionaries Blome described 'were sent to seduce those places to Quakerism, whose success at last caused many to be put to death for Anabaptisme'. ${ }^{44}$

Another group tarred with the same brush, and for many of the same reasons, was the Fifth Monarchists. ${ }^{45}$ William Prynne, attacking John Canne in 1659, therefore condemned the group as 'malicious, inhuman, barbarous, irreligious hypocritical Anabaptists' who aimed 'to make our Land a mere spoyl, Desolation as their Predecessors did Munster, ${ }^{46}$ Although unfair in many respects, ${ }^{47}$ the connection between Fifth Monarchists and violence was pressed home to contemporaries in early January 1661, when Thomas Venner led an abortive uprising in London against the crown. Preacher to a Fifth Monarchist congregation in Coleman Street, Venner was a cooper and returned New England emigre who had already been imprisoned for his involvement in a planned rising against Cromwell in 1657. From 6 to 8 January, the rebels briefly captured St Paul's, fought the trained bands, and killed around twenty soldiers before their eventual defeat. Venner was hanged, drawn, and quartered outside of his own meetinghouse on 19 January. ${ }^{48}$

Although only small in its scale, for many writers Venner's rising confirmed their worst fears about those outside of the national church. As early as 10 January, under the urging of bishop of London Gilbert Sheldon, 'unlawful meetings and conventicles' were banned. Across the next ten days, the government rounded up Quakers and other 'suspicious' nonconformists, while in Edinburgh the Scottish government banned meetings of Quakers, Baptists, and Fifth Monarchists as enemies of authority. ${ }^{49}$ Preaching on the anniversary of

\footnotetext{
${ }^{42}$ Attribution in Moderation, p. 17.

${ }^{43}$ Richard Blome, The fanatick history: or, an exact account of the old Anabaptists and new Quakers (London, 1660), p. 26.

${ }^{44}$ Thomas Underhill, Hell broke loose: or an history of the Quakers both old and new (London, 1660), p. 7.

${ }^{45}$ The best account of the group remains Bernard Capp, The Fifth Monarchy men: a study in seventeenth-century English millenarianism (London, 1972).

${ }^{46}$ William Prynne, The remainder, or second part of a gospel plea (London, 1659), p. 129.

${ }^{47}$ As Timothy G. Shilston has pointed out, Fifth Monarchists cannot be viewed as a specific denominational identity, and congregations varied. The most influential Fifth Monarchists after the failure of the 1653 Nominated Assembly retired quietly from public life (see Shilston, 'Thomas Venner: Fifth Monarchist or maverick?', Social History, 37 (2012), pp. 55-64). Warren Johnston has shown the perseverance of a less vitriolic form of Fifth Monarchism into the later seventeenth century (see Johnston, Revelation restored).

${ }^{48}$ Richard L. Greaves, Deliver us from evil: the radical underground in Britain, 1660-1683 (Oxford, 1986), pp. 49-60; Capp, Fifth Monarchy men, pp. 196-200.

${ }^{49}$ Greaves, Deliver us from evil, pp. 52-6.
} 
Charles I's death, just days after Venner's execution, the Calvinist conformist Simon Ford described Münster as the 'prologue to our tragedy'. ${ }^{50}$ The writer of the descriptively titled Munster paralleld in the late massacres committed by the Fifth Monarchists offered descriptions of events at Münster in regular Roman type, with italicized paragraphs directly comparing them to Venner's rebellion. Like the earlier anti-Quaker work, this made its parallels explicit for example, descriptions of evangelists departing from Münster were immediately followed by an account of Fifth Monarchists sending letters to Ireland and Scotland..$^{51}$ Published later in 1661, the satirical Sir Arthur Haselrig's last will and testament, charged (unfairly) the recently deceased republican with Fifth Monarchism, who looked forward to London breeding 'many John Leydons apt to design a fresh massacre in every circumstance, equal to that memorable one of Munster, ${ }^{52}$ The satirical almanac Poor Robin, published from 1664, continued to make this link by including Venner, van Leiden, and Knipperdollink among the 'fanatics saints days' it listed each year into the eighteenth century. ${ }^{53}$

While some linked this memory to English violence, it was never uncontested. Although Levy and Sznaider emphasize the collaborative nature of cosmopolitan memory across international boundaries, other work has highlighted the ways that different agents can contest it, including those who are being 'remembered'. ${ }^{54}$ While dissenters were pilloried with the memory of Münster, it is important not to overlook their agency in responding. As negative memories of Münster circulated, they scrambled into print in order to deny such links. They had good reason to be concerned. Although traditionally Fifth Monarchists had emphasized separation from other Christian groups, by the late 1650s, some were much more willing to countenance working with 'saints' outside of their gathered churches, as evidenced by the political chaos of 1659-60. A more conciliatory position had appeared in leading Fifth Monarchist Christopher Feake's apologetic A beam of light (1659); even Venner's January manifesto for the rising, A door of hope opened, had tried to build some bridges. ${ }^{55}$ Given the fluidity of denominational labels in the 1650 s and 1660s, particularly for those branded Baptists and Fifth Monarchists by their enemies, ${ }^{56}$ it is understandable that nonconformists

\footnotetext{
${ }^{50}$ Simon Ford, Parallella dysparallela, or The loyal subjects indignation for his royal sovereign's decollation (London, 1661), p. 39.

${ }^{51}$ Munster paralleld in the late massacres committed by the Fifth Monarchists (London, 1661), sig. 4iv.

${ }^{52}$ Sir Arthur Haselrig's last will and testament (London, 1661), p. 3.

${ }^{53}$ Poor Robin. 1664. An almanac after a new fashion (London, 1664) has Venner as the "Fanaticks" saint for 19 January, John of Leiden for 4 May, and Knipperdollink for both 28 September and 1 November. This continued into the eighteenth century, although Venner was dropped in some years, and Leiden disappeared after 1673. Knipperdollink continued to appear until 1698. Venner's name was still appearing in the 1720s.

${ }^{54}$ Pawas Bisht, 'The politics of cosmopolitan memory', Media, Culture \& Society, 35 (2013), pp. 13 20. See also Lorraine Ryan, 'Cosmopolitan memory and national memory conflicts: on the dynamics of their interaction', Journal of Sociology, 50 (2014), pp. 501-14.

${ }^{55}$ Bernard Capp, 'A door of hope re-opened: the Fifth Monarchy, King Charles and King Jesus', Journal of Religious History, 32 (2008), pp. 16-30.

${ }^{56}$ As recently highlighted in Matthew Bingham's work on those traditionally called 'Baptists'. See his Orthodox radicals.
} 
were keen to disassociate themselves from Venner, and, in turn, from actions at Münster.

Connections to the German city were at the forefront of these texts. The Renuntiation and declaration of the ministers of the Congregational churches was signed by twenty-five leaders of the Independent churches, including Joseph Caryll, Philip Nye, and George Cockyane. The Renuntiation established Venner's rising as an event that would be memorialized in similar terms to Münster as a disgrace to Christianity 'Yea, and let down the hateful memory thereof to all ages to come; As that which perhaps cannot be Paralleled, except by those at Munster of the same principle. ${ }^{57}$ Needless to say, Congregationalists were clear that they were connected to neither party. The link with Münster also served to underline the rebels' rejection of infant baptism, further associating Congregationalists, who affirmed the practice, with the Protestant mainstream. ${ }^{58}$ In distinguishing themselves from Baptists, they could also imply the latter's connection to the uprising. This serves as a useful reminder that negative images of dissenters in the period were not just the result of conformist criticism, but also evolved through the competition between different nonconformist groups. ${ }^{59}$

Baptists unsurprisingly both resented and denied these links. If just one member of a separating congregation misbehaved, bemoaned the General Baptist Joseph Wright, their enemies 'will be sure to say that they are all such...as Munster Baptists, and Followers of John of Leyden: whose Heresies, notwithstanding we abhor, ${ }^{60}$ A joint declaration of Particular and General Baptists, also issued in late January, professed loyalty to Charles II and his government, while denying links to Venner and noting that their congregation were 'falsely called Anabaptists', a term that, when applied, now appeared to be 'ground sufficient to question [a man's] Loyalty and fidelity to the Kings Majesty'. ${ }^{61}$ Connections to the rising were as false as connecting a belief in adult baptism with the entire Münster programme; wrongfully taking the actions of a small group of fanatics as representative of a peaceful and obedient majority. ${ }^{62}$ Similarly, Peter Row, a member of the Petty France congregation of Particular Baptists, wrote to vindicate the power of the magistrate in the aftermath of Venner's actions. It was common, he noted, to be told of 'the Munster

\footnotetext{
${ }^{57}$ A renuntiation and declaration of the ministers of the Congregational churches (London, 1661), pp. 1-2.

${ }^{58}$ In a similar way, Edward Legon has shown how invocation of the 'Good Old Cause' appealed beyond just radical groups as a way of shaping a shared notion of positive Protestant solidarity without directly discussing the Civil Wars. We can see Münster as the negative application of the same principle. See Edward Legon, 'Remembering the Good Old Cause', in Edward Vallance, ed., Remembering early modern revolutions: England, North America, France and Haiti (London, 2018), pp. 11-25.

${ }^{59}$ As Alexandra Walsham highlighted in her examination of posthumous representations of Hugh Peter, 'puritans' played a role in constructing 'antipuritan' discourse. See 'Phanaticus: Hugh Peter, antipuritanism and the afterlife of the English Revolution', Parergon, 32 (2015), pp. 73-8.

${ }^{60}$ Joseph Wright, Testimony for the son of man and against the son of perdition (London, 1661), sig. A4iir.

${ }^{61}$ The humble apology of some commonly called Anabaptists (London, 1660/1), p. 6.

${ }^{62}$ Ibid., pp. 5-8.
} 
Anabaptists, and [it is] said, we would do the same if we had opportunity; now how could wee make them ashamed, but by our quiet subjection'? ${ }^{63}$ As Driedger noted, this strategy only served to perpetuate the violent image of Münster by denying association with it, rather than actually questioning the underlying historical narratives behind it. ${ }^{64}$

Venner's rising therefore served as a further conduit for the memory of Münster, already invoked repeatedly in the inter-Protestant struggles during the 1640 s and 1650s, to be directly applied to English events. The existing memory of Anabaptist excess and millennial 'fanaticism' inherited from the histories of the magisterial Reformation had now been enacted on English streets. Claiming this memory identified England's settlement with the norms of European Protestantism, while actively denying connections with Münster similarly allowed nonconformist groups to assert that they held a rightful place in that structure. Quakers, Fifth Monarchists, and English Baptists became, in the eyes of their enemies, Münster Anabaptists. The cosmopolitan memory of Münster in Protestant Europe therefore proved useful in the immediate aftermath of the rising in 1661 in an attempt to heal the wounds of the period, and for nonconformist groups to attempt to claim a valid place in the religious mainstream. In the following years, this would broaden further. In a culture officially encouraged to forget, memories of Münster could recall the horrors of the Civil Wars and Interregnum.

\section{III}

Regardless of protests from Independents and Baptists, the connections between Venner, Münster, and the 'sectaries' merged in the minds of their critics. Over the next decade, as the direct relevance of Venner's rising declined, Münster remained as shorthand for the political chaos of the 1640s and 1650s. The 1660 Act of Indemnity and Oblivion discouraged direct references to the tensions of the period. An official order to both forgive and forget, it was always hamstrung by the fact that any command to forget inevitably resulted in memories of the thing supposed to be forgotten. ${ }^{65}$ Where detailed recollection of the recent past was discouraged, references to symbolic individuals could fill in - for example, one could invoke 'fanaticism' in the 1680s simply by mentioning the regicide preacher Hugh Peter's name. ${ }^{66}$ In a similar way, rather than directly naming supposedly seditious

\footnotetext{
${ }^{63}$ Peter Row, The magistrates power vindicated, and the abominablenesse of resisting their power discovered (London, 1661), p. 8.

${ }^{64}$ Driedger, 'Münster, monster, modernity', loc. 902-4.

${ }^{65}$ Ross Poole, 'Enacting oblivion', International Journal of Politics, Culture and Society, 22 (2009), pp. 149-57; Erin Peters, Commemoration and oblivion in royalist print culture, 1658-1667 (Basingstoke, 2017), pp. 50-5.

${ }^{66}$ On Peter, see Walsham, 'Phanaticus', pp. 86-9. Indeed, Peter and Münster were sometimes linked, as in Robert Conold's, Notion of schism (London, 1676). Conold argued that true priesthood must come from apostolic succession, pointing to 'Knipperdolling or a Hugh Peters' as examples of false priests (p. 3).
} 
dissenting groups and their actions, a reference to Münster could quickly imply the violence inherent within dissent. This had the added benefit of avoiding any direct reference to the Civil War period, while at the same time recalling its chaos. ${ }^{67}$ In this way, Münster, the Civil Wars, and Venner's rising became part of the unified narrative that Matthew Neufeld has traced in Restoration histories of the Civil Wars, whose authors claimed that dissent always led towards political radicalism and subversion of the magistrate. ${ }^{68}$ This image endured long after 1661. Some of this was occasioned by those plots, both real and imagined, linked to groups of dissenters following the ejection of nonconforming ministers in August 1662. The Farnley Wood Plot in 1663, for example, appears to have attracted the support of some Fifth Monarchist, Baptist, and even Quaker congregations (though the latter refused to carry 'carnall' weapons). ${ }^{69}$ The image of the Anabaptist kingdom, which had first reared its head in Münster, was certainly in the authorities' minds. Sir Thomas Gower, deputy lieutenant of the North Riding, wrote to the king's general the duke of Albemarle in August 1663 warning that although the plots seemed to have little hope of success, they demonstrated the danger of nonconformists. Arguments from reason had little effect on fanatics: 'this sort of people, who follow $y^{e}$ fancyes of Anabaptism and $y^{e}$ dreams of those who presently expect to be sharers in a fifth monarchy, doe not govern them selves by such considerations, but earnestly believe what they vehemintly [sic] desire ${ }^{70}$ Indeed, in some respects, the plotters seemed to have deliberately recalled Venner's rising. ${ }^{71}$

Moving into the later 1660s and the following decades, Münster remained an example of the dangers of the Civil Wars. In a 1662 sermon preached before Gray's Inn for the anniversary of Charles II's restoration, Richard Meggott condemned those who looked back to the ecclesiastical chaos of the 1640s and 1650s, 'some to New-England for an Independent Anarchy, some to Munster for an Anabapstisticall Frenzy. ${ }^{72}$ Andrew Honyman, bishop of Orkney, responding to Sir James Stewart's defence of the Pentland Rising in 1668, cited Münster as proof of the dangers of religious toleration. The actions in the German

\footnotetext{
${ }^{67}$ Pollmann notes a similar move among Huguenots after the Edict of Nantes, who commemorated the expulsion of the Templars and the assassination of Henri III in order to recall clerical oppression (Memory in early modern Europe, p. 51).

${ }^{68}$ Neufeld, The Civil Wars after 1660.

${ }^{69}$ Greaves, Deliver us from evil, pp. 179-83.

${ }^{70}$ Thomas Gower to Albermarle, August 1663, The National Archives, State Papers 29/78/18.

${ }^{71}$ As the declaration of Venner's rebels was entitled A door of hope, so was that of the Yorkshire rebels. It similarly called for the pulling down of Gog and Magog, the ending of economic injustice, and an international crusade following their inevitable victory in England. While these were common concerns among Fifth Monarchists, the title, and the potential that Fifth Monarchists around Doncaster may have been involved in a rising designed to coincide with Venner's in London, suggests that there may be greater overlap than has been previously noted. Compare Thomas Venner's A door of hope (London, 1660) and the copy of the Northern 'A door of hope', written by Dr Richardson and reprinted in Evan Childs, Eye-salve for England (London, 1667), pp. 4-7.

${ }^{72}$ Richard Meggott, The new-cured criple's caveat: or England's duty for the miraculous mercy of the king's and kingdomes restauration (London, 1662), p. 33. On the importance of anniversary sermons for constructing a mythic sense of national identity, see Neufeld, The Civil Wars, pp. 203-42.
} 
city recalled the fruits of toleration during the 1640s and 1650s: 'The contagion of this way hath, leß or more, spread itself to some other reformed Churches; and latterly did come to some strength in Britain. ${ }^{73}$ Later in the book, Münster became synonymous with an array of seditious actions, including Hackett's Rising, the assassination of Henri III, and the Gunpowder Plot. ${ }^{74}$ Preaching in February 1670, Joseph Teate, dean of Kilkenny, warned his congregation that 'new light soon turns into Wild-fire, and the Tender Conscience Ravens as a Wolfe, to make havock of the Church; The Arians, and Donatists of old, and Anabaptists in Munster, and Sectaries of England of late have been sufficient Arguments to make this manifest to all men, ${ }^{75}$ As Obediah [sic] Wills concluded in his 1674 examination of Baptist origins, history revealed dissenters to be 'just of the same strain with those they called $5^{\text {th }}$ Monarchy Men that put all London into such a fright some years since'. ${ }^{76}$ Preaching to the judges at York Assizes in July 1676, dean of Ripon Thomas Cartwright urged them to implement the penal laws against dissenters, that the church be not once more dyed Red and imbrued in blood. I need not tell you what the Donatists did in Africa, nor John of Leydens Men at Munster...and we have also smartly felt how hard the Hearts and Hands of those Tender Consciences were. ${ }^{77}$ Discussing the necessity of state limits on dissenters in a funeral sermon the same year, Church of England minister Giles Oldisworth warned of the danger of toleration: 'Should we Britains [sic] forget what we have seen and felt here in England, they at Munster will tell us that sword is un-safe in Anabaptists hands. ${ }^{78}$ The polemicist John Nalson similarly linked sedition of the 1640 s with events in Germany a hundred years earlier: 'As for Anabaptist, Leveller, Quaker $\& c$, let Munster eternally complain of the first, and England of them all. ${ }^{79}$

Neither did these references fade in the following decade. Given the tensions swirling around the succession, warned Surrey minister Henry Hesketh in a 1678 sermon before the lord mayor and aldermen of London, "Rome and Geneva, the Classis and the Conclave, Munster and Leiden' threatened to return England to its pre-Restoration chaos. ${ }^{80} \mathrm{He}$ repeated the same warning when preaching before Charles II six years later. ${ }^{81}$ Similar sentiments were expressed in a sermon preached by Nathaniel Whaley, likely preached around $1680 .^{82}$

\footnotetext{
${ }^{73}$ Andrew Honyman, A survey of the insolent and infamous libel entituled, Naphtali, \&c. (Edinburgh, 1668), p. 4.

${ }^{74}$ Ibid., pp. 106-8.

${ }^{75}$ Joseph Teate, A sermon preached at the cathedral church of St Canice Kilkenny (Dublin, 1670), p. 35.

${ }^{76}$ Obediah Wills, Infant-baptism asserted \& vindicated by scripture and antiquity (London, 1674), p. 399.

${ }^{77}$ Thomas Cartwright, A sermon preached July 171676 (London, 1676), pp. 32-3.

${ }^{78}$ Giles Oldisworth, The father of the faithfull tempted (Oxford, 1676), pp. 60-1.

${ }^{79} \mathrm{John}$ Nalson, The common interest of king and people (London, 1677), pp. 234-5.

${ }^{80}$ Henry Hesketh, A sermon preached before the right honorable lord mayor and aldermen of the City of London at Guild-Hall Chappel (London, 1678), p. 36.

${ }^{81}$ Henry Hesketh, A sermon preach'd before the king in his royal chappel of Windsor, July the $27^{\text {th }} 1684$ (London, 1684), p. 27.

${ }^{82}$ Whalley's sermon was included in a collection published in 1695 , while he was too unwell to undertake ministerial duties. While the sermons were undated, they had been preached across his ministry. A reference to the 1679 murder of James Sharpe, archbishop of St Andrews, as a recent
} 
Speaking on the dangers of a misguided conscience, the rector of Broughton linked the 'Wicked Outrages of the Anabaptists at Munster' to 'the fierce and bloody Attempts, which in our Memory and Nation have been managed upon the fifth Monarchy Principles, ${ }^{83}$ Not to be outdone, in his response to an attack on church forms that he assumed had been written by John Owen, Richard Baxter invoked the Münster rising along with the Civil Wars as proof of the dangers of rigid separatism. Claiming that he would 'pass by the Histories of Muncer [Thomas Muntzer] and Munster', Baxter instead referenced them in the context of the disruption he had 'lived to see'. ${ }^{84}$ Here, he catalogued the chaos and changes in government from 1640 to 1660, particularly the 'Separated Churches of the Anabaptists [who] kept up Religious War in many places' ${ }^{85}$ Critics noticed Baxter's rhetorical sleight of hand, accusing him of engaging in a barely disguised historical smear campaign. ${ }^{86}$ Baxter was not the last to do so. In letters between the General Baptist Thomas Grantham and Church of England minister John Connould in 1691, the latter could still raise the spectre of Münster to rebut Grantham's opposition to infant baptism. ${ }^{87}$

Quakers did not escape censure through these connections either. As in the 1650s and 1660s, the Friends were linked with Münster. Paedobaptists used a 'slippery slope' argument to connect Baptist belief to an inevitable turn towards Quakerism. ${ }^{88}$ In a 1678 attack on Quakers, future dean of Durham Thomas Comber argued that it was important for magistrates to restrain religious enthusiasm. ' $[\mathrm{H}] \mathrm{ad}$ some Persons strength', he warned, 'their Principles might carry them to repeat the Munster Tragedy. ${ }^{89}$ The same year, future bishop of Gloucester Edward Fowler described Leiden and Knipperdollink as both 'the progenitors of our Quakers' and as responsible for the attitude that 'divided this poor nation into innumerable Sects and parties'. ${ }^{90}$ The exiled Scottish Presbyterian John Brown, in his response to Robert Barclay's attack on persecution of his fellow Friends, raised the spectre of the excesses of Civil War sects and events in Germany. Brown claimed Quakers inherited their dislike of human learning from Jan Matthys; they were like Mohammad, Ignatius Loyala, 'and particularly John of Leyden'.91 It was not the state that was guilty of violent persecution, but the "practice of their

event suggests a likely date of 1679-80. See Nathanael Whaley, Eight sermons preached on several occasions (London, 1695), pp. 33-66.

${ }^{83}$ Ibid., p. 45.

${ }^{84}$ Richard Baxter, Catholick communion defended against both extreams (London, 1684), Part IV, pp. 25-6.

${ }^{85}$ Ibid., p. 28.

${ }^{86}$ Hearty Friend to All Good Men, A vindication of the late reverend and learned John Owen D.D. (London, 1684), pp. 17-18.

${ }^{87}$ George Southcombe, 'Dissent and the Restoration Church of England', in Grant Tapsell, ed., The later Stuart church 1660-1714 (Manchester, 2012), p. 207.

${ }^{88}$ Jonathan Warren, "'Out of whose hive the Quakers swarm'd": polemics and the justification of infant baptism in the early Restoration', Perichoresis, 13 (2015), pp. 100-3.

${ }^{89}$ Thomas Comber, Christianity no enthusiasm (London, 1678), p. 20.

${ }^{90}$ Edward Fowler, A vindication of the friendly conference, between a minister and a parishioner of his inclining unto Quakerism (London, 1678), p. 280.

${ }^{91}$ John Brown, Quakerisme, the path-way to Paganisme (Edinburgh, 1678), p. 48. 
Forefathers, the Phanatick Enthusiasts of Munster. ${ }^{92}$ At times, intra-dissenting rivalry could even reinforce the dominant narrative. Stung by Independent minister Thomas Jenner's 'odious comparison' of Quakers 'to the History of John of Leiden, Becold, Copper, Dolling [sic],', William Penn alleged in 1671 that Jenner should have instead compared Quaker fidelity to the recent political history of Independents and Presbyterians: 'whose rank Enmity to all Government, and Scorns of Obedience to all Authority (but their own) have given late evidence how well they love to tread the stage of Usurpation. ${ }^{94}$

As Penn's response suggests, while conformist authors maintained the connections between the Civil War, Venner, and Münster, dissenters unsurprisingly denied them. Although the government and Church of England may have shaped this narrative as a form of 'public remembering', there were ways to contest this. This could be through patterns of 'seditious speech', as traced by Edward Legon, ${ }^{95}$ or the construction of subversive material monuments as Cheryl Kelly has recently noted.${ }^{96}$ Print could also construct counternarratives. This was a pattern already set out in the 1661 declarations disowning any connection to Venner. A common tactic of dissenters was to argue that Catholics used the spectre of Münster to challenge all Protestants. This also worked against the supposed similarities opponents drew between Baptists and Jesuits. The signatories of the Humble apology, for example, reminded the authorities that linking all who were called 'Anabaptist' with John of Leiden's extremist views made no more sense than claiming that all Protestants believed in consubstantiation simply because Luther had held to it. ${ }^{97}$ As the author of the 1669 response to Simon Patrick's Friendly debate between a conformist and a nonconformist noted in An humble apology for non-conformists:

In the beginning of the Reformation, there were a sort of Anabaptists rose up in Germany, and did horrid things at Munster and elsewhere; was the fault therefore in the Reformation? Although the Papists use to charge it upon the Protestant Religion, that it is the Spring and Fountain of Sedition and Rebellion where it is received; Yet both We, and our Brethren Conformists, are able to wipe off that foul aspersion. ${ }^{98}$

\footnotetext{
${ }^{92}$ Ibid., p. 508.

${ }^{93}$ Later editions correct this to 'Knipperdolling'.

${ }^{94}$ William Penn, The second part of the serious apology for the principles \& practices of the people call'd Quakers (London, 1671), p. 161. The first part of this work, by George Whitehead, is bound together with it and maintains pagination. The ESTC entry refers to Whitehead as primary author, although he was only responsible for the first part. Robert Barclay replicates Penn's response to Scottish clerical critics in William Michel unmasqued (Aberdeen, 1672), pp. 2-3.

${ }^{95}$ Edward Legon, Revolution remembered: seditious memories after the British Civil Wars (Manchester, 2019).

${ }^{96}$ Cheryl Kelly, 'Honour, memory and lineage: remembering the English Civil War through funeral memorials', History, forthcoming (2021), doi: 10.1111/1468-229X.13135.

${ }^{97}$ The humble apology of some commonly called Anabaptists, pp. 11-12.

${ }^{98}$ An humble apology for non-conformists (n.p., 1669), pp. 108-9. This is a response to A friendly debate between a conformist and a non-conformist (London, 1669) by Simon Patrick, who later became bishop of Colchester and then Ely.
} 
Similarly, Thomas Grantham's Christianismus primitivus reprinted the 1661 Humble apology as evidence of both Baptists' continuing loyalty, and the unjust accusation that continued to claim their involvement in Venner's rising. ${ }^{99}$

Disputes around Münster therefore often centred on historiography, and, as George Southcombe notes, prompted many dissenters to turn to the writings of sixteenth-century churchmen for support. ${ }^{100}$ Indeed, they frequently used Catholic historiography. Georgius Cassander's sixteenth-century work, in which he argued that the Münster Anabaptists were unrepresentative of the majority, was particularly widely quoted. Cassander was a popular choice, partly due to his attempts to reunite Catholics and Protestants and closeness to Protestant theological positions. That his works were placed on the Index Librorum Prohibitorum in 1617 did his reputation among Protestants readers no harm at all. ${ }^{101}$ The 1661 Humble apology, for example, cited 'what Cassander, a learned and moderate Papist, relates in his Epistle to the Duke of Gulick and Cleve'. There, the historian had taken notice of

certain people in Germany bearing the denomination of Anabaptists, who resisted and opposed the opinions and practices of those at Munster, and taught the contrary Doctrine, Whereby (in his opinion) they appeared to be incited by a Godly mind, and rendered themselves rather worthy of pity then persecution and perdition.

Cassander, noted the signatories, later went on to recognize that Anabaptism was most commonly associated with pacifism. ${ }^{102}$ Grantham's 1662 metrical dialogue between the prison and cathedral of Lincoln picked up the refrain, responding to the charge of being 'of Leiden breed, of Munster' with the defence that 'Munster, 'gainst whose pranks I did protest / Even in those dayes as Cassander hath prest / Me forth in Print, and sith he doth acquit me / Thy Callumny in this case cannot hit me. ${ }^{103}$

Particular Baptist Henry Danvers's important 1673 apologetic work, A treatise of baptism, used similar arguments. Like the 1661 Apology, Danvers worked to suggest that his opponents were resorting to anti-Reformation strategies to attack Baptists, therefore condemning themselves. He noted that Catholics had used the Peasants' War to argue for an intrinsic link between reformation belief and rebellion, something that most Protestants would readily disown. Nonetheless, he observed, while denying one link due to faulty logic, they were willing to assert another on the same basis: 'upon as good grounds as the Protestants have since reflected upon the Anabaptists, because there

${ }^{99}$ Thomas Grantham, Christianismus primitivus, or, The ancient Christian religion (London, 1678), Bk 3, p. 7.

${ }^{100}$ Southcombe, 'Dissent'.

${ }^{101}$ Rob van de Schoor, 'De invloed van Georgius Cassander op de Engelse theologie in de zeventiende eeuw', Nederlands archief voor kerkgeschiedenis / Dutch Review of Church History, 77 (1997), pp. 158-95.

${ }^{102}$ Humble apology, p. 7.

${ }^{103}$ [Thomas Grantham], The prisoner against the prelate: or, a dialogue between the common goal [sic] and cathedral of Lincoln ([Lincoln?], 1662), p. 16. 
were some of their persuasion concerned in that attempt for freedom'. ${ }^{104}$ Ironically, in using this strategy, Protestants were acting like Papists. ${ }^{105}$ Robert Barclay's 1678 apology for the Quakers made a similar point. Those who wrongly saw Münster as the logical outcome of following the Spirit's leading ignored the violence and rebellion by those who justified them through their supposed orthodoxy. Although abhorring 'those wild Practices, which are written, concerning the Anabaptists of Munster; I am bold to say as bad if not worse things have been committed by those that lean to Tradition, Scripture, and Reason'. ${ }^{106}$

Münster, of course, remained a powerful contemporary image due to historical knowledge of events in the city. Some Baptists therefore went as far as adopting the strategy of dismissing standard Protestant histories in order to defend their German forebears. Their readings challenged the dominant historiography. Dissenters' critics were particularly fond of the works of Johannes Sleidan and Dutch anti-Baptist writer Frederick Spanheim ${ }^{107}$ with relevant parts of the latter's work translated and republished in $1646 .^{108}$ Sleidan's firm defence of the magistrate, in which Münster Anabaptists existed primarily 'to subverte all lawes and common wealth', ${ }^{109}$ was particularly clear in tying rejection of infant baptism to attempts to overthrow established religious authorities. ${ }^{110}$ In response, the 1660 Gorgon's head, or the monster of Munster charged that Papists had massacred the Anabaptists in the city in order to stop their true beliefs being known - and accused Presbyterians of desiring the same fate for their co-religionists. ${ }^{111}$ More influentially, Danvers applied a variety of often-contradictory revisionist strategies. He agreed with Catholic historians that Münster was already prone to violence in the Lutheran stage of its reformation, while also claiming that Sleidan's histories were unreliable as they were based on works written by 'malicious Papists'. ${ }^{112}$

\footnotetext{
${ }^{104}$ Henry Danvers, A treatise of baptism (London, 1673), p. 324.

${ }^{105}$ Ibid., p. 322.

${ }^{106}$ Robert Barclay, An apology for the true Christian divinity (London, 1678), p. 31.

${ }^{107}$ For example: Prynne, The remainder, pp. 128-9; George Pressick, A breife [sic] relation, of some of the most remarkable passages of the Anabaptists (London, 1660); Thomas Gery, A mirrour for Anabaptists (London, 1660), pp. 40-1; H. S., Toleration with its principal objections fully confuted (London, 1663), pp. 11-12.

${ }^{108}$ Frederick Spanheim, Englands warning by Germanies woe (London, 1646). As the title suggests, the printed annotations to the work draw comparisons between the perilous situation of England and the German experience. The Münster Anabaptists' actions are used as a warning of the danger of toleration: 'They [Anabaptists] not content with liberty of conscience, aspire to the government according to their own pleasure' (p. 14).

${ }^{109}$ Johannes Sleidanus, A famouse cronicle of oure time, called Sleidanes commentaries (London, 1560), fo. 133r. The Münster narrative is at the start of Book 10, and runs from fos. $127 \mathrm{r}$ to $138 \mathrm{v}$.

${ }^{110}$ Euan Cameron notes that Sleidan emphasized stable political establishment as crucial for the church's well-being: 'If anything, the marks of a Church were defined by its conformity with the norms of the secular political community' ('Primitivism, patristics, and polemic in Protestant visions of early Christianity', in Katherine Van Liere, Simon Ditchfield, and Howard Louthan, eds., Sacred history: uses of the Christian past in the Renaissance world (Oxford, 2012), p. 41).

${ }^{111}$ The gorgon's head, or the monster of Munster (London, 1660), pp. 1-4.

${ }^{112}$ Danvers, Treatise of baptism, p. 325.
} 
Most significantly, he argued that given disputes in England over the Civil Wars, it was unlikely that the contested events at Münster could have been reported accurately. The manifold inaccuracies in Edwards's Gangraena in attacking Independents and Baptists, Richard Baxter's spurious claims of naked baptisms in England, and the disagreements over interpretation of events of the 1640s and 1650s showed that 'if the matter of fact cannot better be told amongst our selves at home, what may we expect of it abroad at such a distance?'. ${ }^{113}$ These suggestions were risky ones. Danvers came close to appearing to rehabilitate John of Leiden in his scepticism about the nature of the conventional historical claims. ${ }^{114}$

This approach generated angry responses from Obediah Wills and Richard Baxter, who felt unfairly slighted for his opinion. ${ }^{115}$ Wills, an ejected Wiltshire rector viewed by conformists as a 'bad, though Godly, neighbour', ${ }^{116}$ feared the effects that Danvers's undermining of orthodox history would have. 'These historians', noted Wills, 'cannot be so put off; for they are punctual, name Persons, Time, Place Opinions, Condemnation, and Punishment, all matters of Fact open to the World. ${ }^{117}$ Flipping Danvers's strategy on its head, he quoted John Tombes' 1646 defence of adult baptism, in which he openly acknowledged the atrocities enacted at Münster. This, claimed Wills, was at least an honest admission compared to Danvers's revisionism. Echoing Baxter, Wills worried that if the magisterial reformers' own histories could not be trusted, 'then we may call in question the truth of all History whatsoever'. ${ }^{118}$ Danvers, engaging in an exchange of treatises with Wills, accused Sleidan of being unable to assess the provenance of his sources: 'For Sleidan wrote not his commentary till 1555 about twenty years after the fact...and as for Spanhemius he wrote not till eighty years after Sleidan. ${ }^{119}$ In a triumphant bit of historical nit picking, he also noted that Wills claimed that Zwingli wrote about Münster: an impressive achievement given that he had died three years before the events began. ${ }^{120}$

The Münster comparison received a new lease of life between the aftermath of the Popish Plot and the death of Charles II. Tory apologists were keen to point out similarities between the anti-Catholic hysteria, Münsterites, and

${ }^{113}$ Ibid., p. 326. Baxter responded in More proofs of infants church-membership and consequently their right to baptism (London, 1675). He claimed that he had lived near the Baptist minister John Tombes, who while he did not engage in naked baptisms himself, did not deny that the practice took place (pp. 281-3).

${ }^{114}$ Michael Driedger notes the extremely limited nature of Baptist defences of the Münsterites themselves, identifying The monster of Munster as a rare example to the contrary. Driedger, 'Münster, monster, modernity', loc. 1074-88.

${ }^{115}$ Baxter, More proofs, pp. 281-3. Wills alleged that Danvers 'seems to entertain a better opinion of John of Leyden, than of him [Baxter]' (Infant-baptism, sig. A2r).

${ }^{116}$ John Walker, An attempt towards recovering an account of the numbers and sufferings of the clergy of the Church of England (London, 1714), p. 417.

${ }^{117}$ Wills, Infant-baptism, p. 407 [misl. 107].

${ }^{118}$ Ibid., p. 393. Cf. John Tombes, An apology or plea for the two treatise (London, 1646), p. 30.

${ }^{119}$ Henry Danvers, Innocency and truth vindicated: or, a sober reply to Mr Will's answer to a late treatise of baptisme (London, 1675), p. 153.

${ }^{120}$ Ibid., pp. 154-8. 
Civil War-era chaos. The 1683 True loyalist, for example, made suggestive links between the Cromwellian protectorate and the Anabaptist rising in an echo of Ford's post-Vennerite lament: 'When was there ever more slavery and bondage in the State? And when more Anarchy and confusion in the Church? Munster it self saw but the Prologue to our Tragedy. ${ }^{121}$

In a more promising setting, Baptists continued their attacks on the standard reformed historiography after the Glorious Revolution. Benjamin Keach's 1689 apology for the Baptists, Gold refin'd, thus answered an imagined interlocutor raising the spectre of 'that old Munster-story of John of Leyden'. '[T]hey that read the best Histories of that business', he argues, 'may find many things to be false which are charged against those Anabaptists.' Besides, he warned, the histories were written by 'malicious Papists' or 'envious Protestants, who are willing to take up any base Reports, and improve those stories to blast the Reputation of the whole Party'. ${ }^{122}$ Keach's words were echoed (or freely plagiarized) in Hercules Collins's Believers baptism from heaven (1691), a short book that also repeated Danvers's claims about Sleidan's inaccuracy. ${ }^{123}$

Memories of Münster therefore remained contested by Baptists. Yet, this does not challenge their role as a form of cosmopolitan memory in post-Civil War England. The widespread nature of the popular interpretation of Münster, and its links to English political violence, made it necessary for such contestation to take place. While the city's history was undoubtedly used as a form of the 'public remembering' of the Civil Wars traced by Neufeld, its longer provenance in sixteenth-century anti-Anabaptist works allowed it to be accessed and applied by Presbyterians and Congregationalists as much as by establishment Anglicans. In doing so, they could make use of the cosmopolitan memory of Münster in order to simultaneously deny their own connections to the chaos of the 1640s and 1650s, and to position themselves as within mainstream Reformation orthodoxy.

\section{IV}

The use of Münster as an archetypal example of religious violence in early modern England is well known, but has not been systematically examined in detail. The trope's resilience demonstrates its importance to the ways in which early modern writers understood Baptists and other dissenting groups in the years following the Restoration. The concept of "cosmopolitan memory" can help us understand how a communal memory of an atrocity was adapted to local conditions, and effectively transposed to England as a way of remembering local instances of religious violence. This memory served as a healing ritual in reiterating the defeat of 'fanatics', and in connecting English Protestantism to the mainstream of the Reformation, emphasizing transnational religious solidarity. As Bisht has argued, however, 'cosmopolitan

\footnotetext{
${ }^{121}$ The true loyalist (London, 1683), p. 29.

122 Benjamin Keach, Gold refin'd; or, baptism in its primitive purity (London, 1689), pp. 158-9.

${ }^{123}$ Hercules Collins, Believers baptism from heaven, and of divine institution (London, 1691), pp. 100-7.
} 
memory' is never uncontested ${ }^{124}$ - Baptists, Quakers, and others used print as a way of reinterpreting the memory and its implications for their place within the national structure.

There is a danger in applying contemporary theory to the early modern period. However, thinking about invocations of Münster as 'cosmopolitan memories' that aimed to help to re-establish the religious status quo provides a helpful way of analysing what these memories do. Münster became a convenient cultural reference with which to attack nonconformity, and to efface differences between dissenting groups for Church of England writers. As the German Anabaptists morphed, in some narratives, into Quakers and Fifth Monarchists, so the memory of Münster became the memory of the religious chaos of the 1640s and Venner's rising. This continues to have implications for Reformation historiography today. Even in the twenty-first century, shorthand references to apocalyptic Anabaptist violence by historians, political scientists, and journalists efface the more complex story of events in the city. Pop culture links between Münster and 'Anabaptist vampires'125 or global conspiracies ${ }^{126}$ are perhaps amusing, but show the continued power of the historiographical approach first developed in the early modern period, providing a testimony to its enduring power. This article therefore provides a case-study of one way in which cosmopolitan memories of religious violence can continue to negatively impact religious minorities, and shape popular historical interpretations.

Yet, for all of the continuities in the historiography of the events of 1534-5, their particular application varies in different times and places. Being more closely attuned to the regional adaptations in European Protestant memory culture, and their specific resonances within local contexts, provides historians of the period with new insights into the way in which collective memory could be both broadly shared on the macro-level, and retain specific implications at the micro-level. In post-Restoration England, Münster therefore became particularly powerful. As John Seed has suggested, understandings of dissent were driven by the constructions of narrative identity-identity that, in large part, depended on historical interpretation. ${ }^{127}$ This suggests the reason why the ghost of Münster proved so difficult to exorcize, well into the following century. ${ }^{128}$ In 1738 , Thomas Crosby noted in his landmark history of the

\footnotetext{
${ }^{124}$ Bisht, 'The politics of cosmopolitan memory', p. 14.

125 Driedger cites the 1999 novel by Mark Barkawitz (as C. W. Bach) Mark Hellmann, dämonenjäger: wiedertäufer-vampire. Driedger, 'Münster, monster, modernity', loc. 927.

${ }^{126} \mathrm{Mr}$. Robot (USA Network, 2015-19). For a use of Münster as the backdrop of an acclaimed novel, see Luther Blissett, $Q$ (London, 2003).

${ }^{127}$ John Seed, 'History and narrative identity: religious dissent and the politics of memory in eighteenth-century England', Journal of British Studies, 44 (2005), pp. 46-63.

${ }^{128}$ There is not room here to explore the trope in the eighteenth century, but it continued to appear in attacks against Baptists (e.g. John Ball, The Anabaptists teachers no ministers of Christ (London, 1708), pp. 108-9; Richard de Courcy, The rejoinder (Shrewsbury, 1777), pp. 127-30), Quakers (e.g. Daniel Defore, D'foe's answer to the Quakers catechism (London, 1706), p. 9), Methodists (e.g. George Lavington, The enthusiasm of Methodists and Papists compared. Part II (London, 1752), p. 161; Alexander Jephson, A friendly and compassionate address to all serious and well-
} 
English Baptists, the 'extravagant doctrines, and seditious practices' of the Münster Anabaptists continued to be 'every where charged upon the opposers of infant baptism'. ${ }^{129}$ As English Baptist leader Robert Hall complained in 1816, 'there are not wanting persons who seem anxious to revive the recollection of Munster, and by republishing the narrative of the enormities perpetrated there...[and] so implicate us in the infamy and guilt of those transactions'. ${ }^{130}$ Münster, it seemed, was difficult to forget.

Acknowledgements. I am grateful for the constructive comments from the journal's anonymous readers in helping to shape and improve the final article, as well as helpful feedback on earlier drafts from Crawford Gribben and Rosamund Oates. Audiences of condensed versions of this article at Liverpool and Keele also provided valuable suggestions and helped open new avenues of investigation.

disposed Methodists (London, 1761), pp. 41-2); French Prophets (e.g. [Charles Chauncy?], The wonderful narrative (Glasgow, 1742), pp. 73-80), and Bourignonists (e.g. George White, An advertisement, anent the reading of the books of Antonia Borignion (Aberdeen, 1700), p. 37). Events at Münster were also linked to the Civil Wars (e.g. Richard de Courcy, A word to Parmenas (Shrewsbury, 1776), pp. 9-10; [Anon.], A brief vindication of the appointment of God (Canterbury, 1789), pp. 29-30).

${ }^{129}$ Daniel Crosby, The history of English Baptists, I (London, 1738), p. xxiv. Links to Münster were refuted repeatedly in Baptist apologetics - e.g. Joseph Hooke, A necessary apology for the baptized believers (London, 1701), pp. 5-19; Joseph Jenkins, A calm reply (Wrexham, 1778), p. 7.

${ }^{130}$ Robert Hall, On terms of communion (Philadelphia, PA, 1816), pp. 187-8. I owe this reference to Crawford Gribben.

Cite this article: Crome A (2022). The Münster Rising, Memories of Violence, and Perceptions of Dissent in Restoration England. The Historical Journal 65, 946-968. https://doi.org/10.1017/ S0018246X21000674 